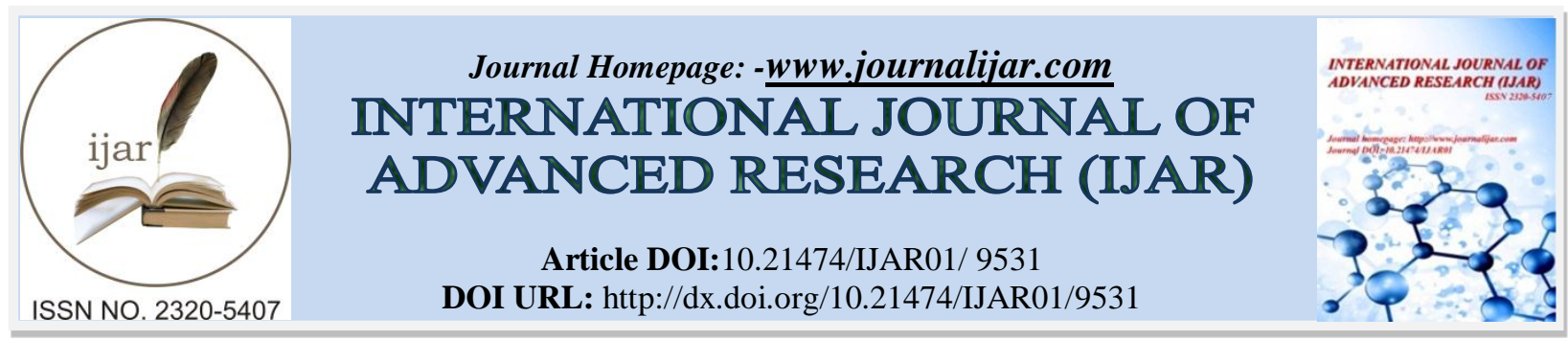

RESEARCH ARTICLE

\title{
SOCIAL AND ECONOMIC LIFE OF SCAVENGERS: A CASE STUDY OF AMROHA CITY.
}

Zaid Alam ${ }^{1}$ and Dr. Fatma Mehar Sultana ${ }^{2}$.

1. Research Scholar, Department of Geography, Aligarh Muslim University, Aligarh, India.

2. Assistant Professor, Women's College, Aligarh Muslim University, Aligarh, India.

\section{Manuscript Info}

Manuscript History

Received: 06 June 2019

Final Accepted: 08 July 2019

Published: August 2019

Key words:-

scavengers, manual scavengers, social and economic life, socio-economic causes, problems among scavengers, and Amroha city.

\begin{abstract}
The present paper attempts to analyse the social and economic life of scavengers in Amroha city. The study is based on the primary source of data collected through the personal interview to the respondents in the city. The field survey is carried out during August 2018. The study reveals that scavengers belong to one of the most vulnerable or poverty-stricken groups, and they are facing the problem of untouchability in a society. Majority of the scavengers belong to the Hindu caste of Bhangi and Chamar who comes in a group of schedule caste. Besides, Majority of them live with poor housing condition, lack of education, lack of awareness and the problem untouchability in a society. Social causes are predominant among the socio-economic causes of scavenging.
\end{abstract}

Copy Right, IJAR, 2019,. All rights reserved.

\section{Introduction:-}

The community of scavengers is one of the weaker sections of the society. A significant attribute of the Indian caste system is that traditional employment is associated with each caste. The caste system delivers a hierarchy of social status that holds inherent characteristics and remains stable throughout life (Dirks, 1989). The higher castes benefit from a wide range of choices in occupations, while the dirty jobs got associated with lower castes. The caste of the scavengers are known by various names in various region like Bhangi, Balmiki, Chuhra, Mehtar, Mazhabi, Lal Begi, Halalkhor, etc. in northern India; Har, Hadi, Hela, Dom and Sanei, etc. in eastern India; Mukhiyar, Thoti, Chachati, Pakay, Relli, etc. in Southern India and Mehtar, Bhangis, Halalkhor, Ghasi, Olgana, Zadmalli, Barvashia, Metariya, Jamphoda and Mela, etc. in Western and Central India (Srivastava, 1997). The group of scavengers is placed lowest in the caste-based hierarchy and engaged in jobs such as cleaning drains and sewers, removal of human and animal waste, leather processing, etc. (Baruah, 2014). They are bound by not only traditional obligations and customary rules to practice this ubiquitous occupation, but mythological sanctions also oblige them. The social status of some scavenges better than others; the type of their work determines their rank. The group of scavengers, which removes human and animal excreta using brooms, small tin plates, and baskets carried on the head, are untouchables among the untouchables. The inhumane manual scavenging practice enslaves an estimated 1.2 million people in India. They belong to scheduled caste and placed in the lowest stage of Hindu society. Manual scavenging is one of the most cold-hearted and degrading forms of work performed by mainly Dalit women. The people from this community face the problems of untouchability and social boycott in society and live in a location that is isolated from the rest of the village community. In spite of India's rapid economic growth in recent years, manual savaging is still one of the biggest and serious problems in India. By the Government of India, The Employment of Manual Scavengers and Construction of Dry Latrines (Prohibition) Act was introduced in 1993.

Corresponding Author:-Zaid Alam.

Address:-Research Scholar,Department of Geography Aligarh Muslim University, Aligarh, India. 
Besides, The Prohibition of Employment as Manual Scavengers and their Rehabilitation Bill was passed in the Lok Sabha on $3^{\text {rd }}$ September 2012 by Minister of Social Justice and Empowerment, Government of India. Even after making a law, the practice of manual scavenging is still prevalent in India from Kashmir to Kanyakumari; from backward states to developed states.

Thus, the community of scavengers is one of the socio-economic weakest section of the society not only in India but also in the developed nations. This community has been suffering from various problems such as low income, poverty, lack of basic amenities, illiteracy and ignorance, untouchability, discrimination, and so on. Therefore, the present study entitled "Social and Economic Life of Scavengers: A Case Study of Amroha City" tries to analyse the social and economic status of scavengers and also identify the problems that are faced by them.

\section{Objectives:-}

1. To illustrate the social and economic status of scavengers in Amroha city.

2. To find out the causes of scavenging.

3. To identify the problems that are faced by scavengers.

\section{Study Area}

Amroha is a city in the Indian state of Uttar Pradesh, located north-west of Moradabad, near the Sot River. It is a headquarter of the Amroha district. The city extends from $28^{\circ} 52^{\prime} 37^{\prime \prime} \mathrm{N}$ to $28^{\circ} 55^{\prime} 22^{\prime \prime} \mathrm{N}$ latitude, and from $78^{\circ} 26^{\prime} 26^{\prime \prime}$ E to $78^{\circ} 29^{\prime} 24^{\prime \prime}$ E longitude. For administrative purpose, the city is divided into 31 wards. The climate of the region is similar to other districts of the state that sited at the base of the Himalayas, i.e. hot summer and dry and cold winter. Ganga, Baha and Krishna are the main rivers of the district. According to data from census 2011, Amroha has a population of 198,471. The population of the children (age group of 0-6 years) is 28323, which is recorded 14.27 per cent of the total population of Amroha city. Female sex ratio is of 925 against the state average of 912 . Besides, Child Sex Ratio in Amroha is around 950 compared to Uttar Pradesh state average of 902. The literacy rate of the city is 62.36 per cent lower than the state average of 67.68 per cent. Moreover, Amroha city is known for the production of mangoes and some of the cottage and small industries, i.e. carpet manufacturing, wood handicrafts and dholak manufacturing, handloom weaving, and pottery making.

Figure 1:-Locational Map of the Study Area.

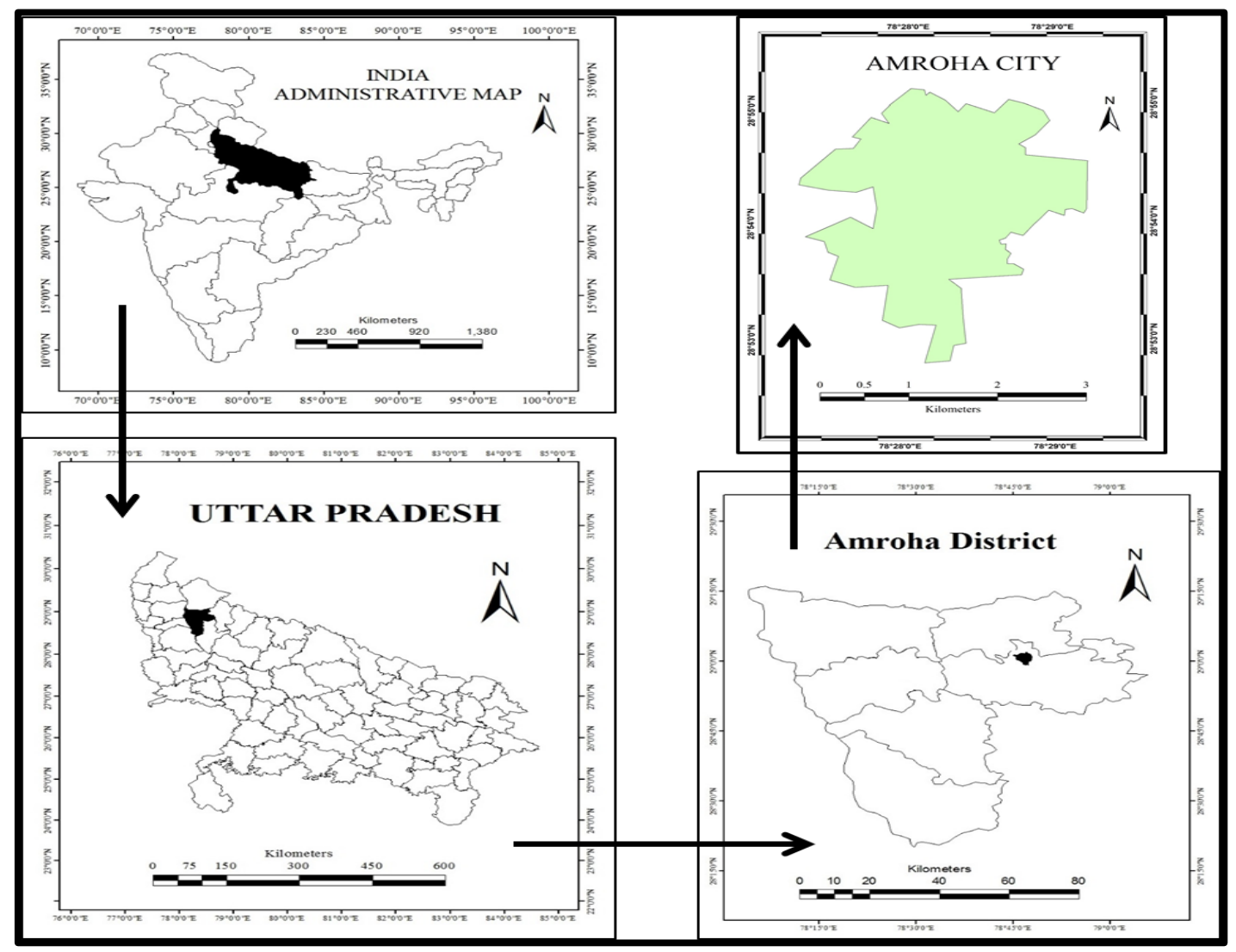




\section{Database and Research Method}

The study is based on the primary source of data, collected through the direct questionnaire to the respondents with the help of a well-structured questionnaire. The survey was carried out during August 2018. Before the survey, a pilot survey has been made to identify the areas of concentration of the scavengers in the city. From the selected places, 110 scavengers are randomly interviewed for the collection of the relevant data in Amroha City. After the survey, each of the individual slip is scrutinised, and the data is processed in the tabular form according to the requirement of the various aspects of the study. The second attempts to the transformation of data on individual variables into a simple percentage. For cartographic presentation, ArcGIS 10.5 and MS Excel 2016 are used.

\section{Result and Discussion:-}

\section{Social and Economic Status}

Age and Sex Composition:

Table 1 shows the age and sex composition of scavengers in Amroha city. Out of total scavengers, about two-fifth proportion of the scavengers are belonging to the age group of 35-50 years followed by scavengers who belonged to 18-35 years of age-groups (35.45 percent), 50-65 years of age (20 percent), above 65 years of age (4.55 percent) and below 18 years of age (0.91 percent) respectively in the study area. Further, among the scavengers, the number of males is higher than females. Among the males, about 35 per cent scavengers' belonged to 35-50 years of age groups, which is recorded maximum, while the minimum (1.35 per cent) belonged to below 18 years of age groups. The proportion of the female scavengers is witnessed highest (47.22 per cent) who belonged to 35-50 years of age groups and the lowest (2.78 per cent) who belonged to above 65 years of age groups, and even no single female scavenger belonged to below 18 years of age in the Amroha city.

Table 1:-Percentage Distribution of Age and Sex Composition of Scavengers in Amroha City.

\begin{tabular}{|l|l|l|l|l|l|l|}
\hline \multirow{2}{*}{ Age \& sex Composition } & Male & Female & \multicolumn{1}{l|}{ Total } & Percent \\
\cline { 2 - 7 } & Number & Percent & Number & Percent & Number & Pmb. \\
\hline Below 18 & 1 & 1.35 & 0 & 0.00 & 1 & 0.91 \\
\hline $18-35$ & 25 & 33.78 & 14 & 38.89 & 39 & 35.45 \\
\hline $35-50$ & 26 & 35.14 & 17 & 47.22 & 43 & 39.09 \\
\hline $50-65$ & 18 & 24.32 & 4 & 11.11 & 22 & 20.00 \\
\hline Above 65 & 4 & 5.41 & 1 & 2.78 & 5 & 4.55 \\
\hline TOTAL & $\mathbf{7 4}$ & $\mathbf{1 0 0 . 0 0}$ & $\mathbf{3 6}$ & $\mathbf{1 0 0 . 0 0}$ & $\mathbf{1 1 0}$ & $\mathbf{1 0 0 . 0 0}$ \\
\hline
\end{tabular}

Source: Based on Field Survey, August 2018.

\section{Religion and Caste:}

Table 2 shows that religion and caste wise occupational structure of scavengers in Amroha city. Out of sampled scavengers, mostly are Hindu (nearly 90 per cent), while only 10 per cent belong to Muslims community. Caste wise analysis reveals that Bhangi caste is predominant (almost 54 per cent), followed by chamar (30 per cent). Besides, manual scavenging is done mostly by Hindus caste of Bhangi and Chamar. While no one manual scavengers are found in Muslim community.

Table 2:-Percentage Distribution of Caste, Religion and Occupation Type of Scavengers.

\begin{tabular}{|c|c|c|c|c|c|c|c|}
\hline \multirow[t]{3}{*}{ Religion } & \multirow[t]{3}{*}{ Caste } & \multirow{2}{*}{\multicolumn{2}{|c|}{ Scavengers }} & \multicolumn{4}{|c|}{ Occupation Type } \\
\hline & & & & \multicolumn{2}{|c|}{ Manual Scavengers } & \multicolumn{2}{|c|}{ Others Scavengers } \\
\hline & & Number & Percent & Number & Percent & Number & Percent \\
\hline \multirow[t]{3}{*}{ Hindu } & Bhangi & 60 & 54.55 & 11 & 18.33 & 49 & 81.67 \\
\hline & Chamar & 33 & 30.00 & 3 & 9.09 & 30 & 90.91 \\
\hline & others & 6 & 5.45 & 1 & 16.67 & 5 & 83.33 \\
\hline \multirow[t]{3}{*}{ Muslim } & Mirasi & 4 & 3.64 & 0 & 0.00 & 4 & 100.00 \\
\hline & Fakeer & 5 & 4.55 & 0 & 0.00 & 5 & 100.00 \\
\hline & others & 2 & 1.82 & 0 & 0.00 & 2 & 100.00 \\
\hline Others & & 0 & 0.00 & 0 & 0.00 & 0 & 100.00 \\
\hline Total & & 110 & 100.00 & 15 & 13.64 & 95 & 86.36 \\
\hline
\end{tabular}

Source: Based on Field Survey, August 2018. 


\section{Marital Status:}

Table 3 depicts the marital status of scavengers in Amroha city. According to the table, about 60 per cent of scavengers is married. While nearly 17 per cent, 16 per cent and 6 per cent are widowed, unmarried, and divorced respectively. Moreover, the comparison between the marital status of males and females are also given. Among males, mostly (nearly 60 per cent) are married, 20 per cent comes under the group of unmarried, and remaining belong to the widow and divorced category. While among females, the categories of married, widows, divorced and unmarried constitute nearly 58 per cent, 25 per cent, 11 per cent and 5 per cent respectively.

Table 3:-Percentage Distribution of Marital Status of Scavengers.

\begin{tabular}{|l|l|l|l|l|l|l|}
\hline \multirow{2}{*}{ Marital Status } & Male & Female & Total \\
\cline { 2 - 7 } & Number & Percent & Number & Percent & Number & Percent \\
\hline Married & 45 & 60.81 & 21 & 58.33 & 66 & 60.00 \\
\hline Unmarried & 16 & 21.62 & 2 & 5.56 & 18 & 16.36 \\
\hline Widows & 10 & 13.51 & 9 & 25.00 & 19 & 17.27 \\
\hline Divorced & 3 & 4.05 & 4 & 11.11 & 7 & 6.36 \\
\hline Total & $\mathbf{7 4}$ & $\mathbf{1 0 0 . 0 0}$ & $\mathbf{3 6}$ & $\mathbf{1 0 0 . 0 0}$ & $\mathbf{1 1 0}$ & $\mathbf{1 0 0 . 0 0}$ \\
\hline
\end{tabular}

Source: Based on Field Survey, August 2018.

Educational Status:

Table 4 presents the percentage distribution of the literate person and level of education among scavengers. It is clear from the table that there is mass illiteracy among the scavengers (about 70 per cent) because they do not get register in school due to low income.

Table 4:-Literacy Rate and Educational Level of Scavengers in Amroha City.

\begin{tabular}{|l|l|l|l|l|l|l|l|}
\hline \multirow{2}{*}{ Literacy status } & \multirow{2}{*}{ Level of Education } & \multicolumn{2}{l}{ Male } & \multicolumn{2}{l|}{ Female } & Total \\
\cline { 3 - 8 } & & Number & Percent & Number & Percent & Number & Percent \\
\hline Illiterate & & 49 & 70.27 & 27 & 75.00 & 79 & 71.82 \\
\hline Literate & & 25 & 29.73 & 9 & 25.00 & 31 & 28.18 \\
\hline Total & & $\mathbf{7 4}$ & $\mathbf{1 0 0 . 0 0}$ & $\mathbf{3 6}$ & $\mathbf{1 0 0 . 0 0}$ & & $\mathbf{1 0 0 . 0 0}$ \\
\hline & & 9 & 40.91 & 5 & 55.56 & 14 & 45.16 \\
\hline & Primary & 7 & 31.82 & 3 & 33.33 & 10 & 32.26 \\
\hline & Secondary & 5 & 22.73 & 1 & 11.11 & 6 & 19.35 \\
\hline & Sr. Secondary & 1 & 4.55 & 0 & 0.00 & 1 & 3.23 \\
\hline Total & Graduate & 1 & $\mathbf{1 0 0 . 0 0}$ & & $\mathbf{1 0 0 . 0 0}$ & & $\mathbf{1 0 0 . 0 0}$ \\
\hline
\end{tabular}

Source: Based on Field Survey, August 2018.

Among the literate population, 45.16 per cent scavengers are educated up to primary level, 32.26 per cent are up to secondary, 19.35 per cent are qualified intermediate, and only one male scavenger is found graduated. While no one is educated above intermediate among female scavengers.

Figure 2:-Educational Status of Scavengers in Amroha City.

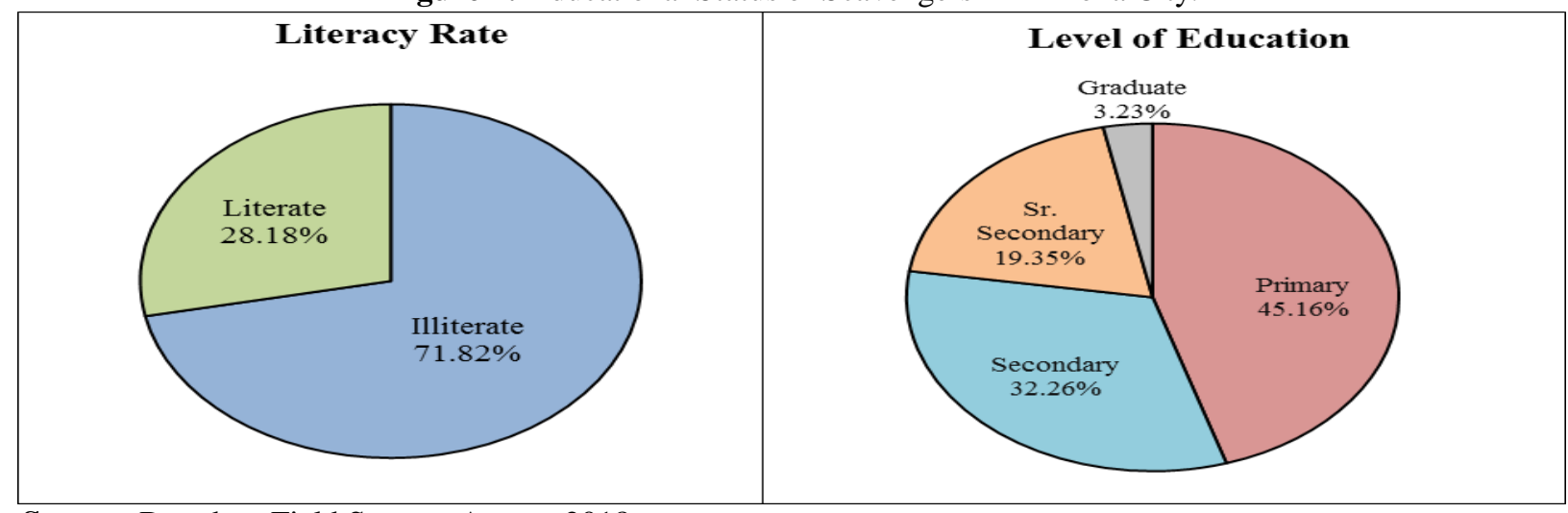

Source: Based on Field Survey, August 2018. 


\section{Family Status:}

Table 5 gives information on scavengers' family status. Almost three-fourths of them belong to a nuclear family, whereas the rest of them to the Joint family. Besides, Nearly 20 per cent belong to the family that have less more than ten members. In the study area, about one-fourth of sampled scavengers allow their children for getting an education. While the children of 70 per cent scavengers engaged as child labours or as scavengers.

Table 5:-Family Status of Scavengers in Amroha City.

\begin{tabular}{|l|l|l|}
\hline Family Type & Number & Percent \\
\hline Joint & 36 & 32.73 \\
\hline Nuclear & 74 & 67.27 \\
\hline Total & $\mathbf{1 1 0}$ & $\mathbf{1 0 0 . 0 0}$ \\
\hline Total Members in a family & & \\
\hline less 4 & Number & Percent \\
\hline $4-7$ & 12 & 10.91 \\
\hline $7-10$ & 34 & 30.91 \\
\hline more than10 & 41 & 37.27 \\
\hline Total & 23 & 20.91 \\
\hline & $\mathbf{1 1 0}$ & $\mathbf{1 0 0 . 0 0}$ \\
\hline Status of the children & & \\
\hline Go to school & Number & Percent \\
\hline Scavenging & 29 & 26.36 \\
\hline Child labour & 35 & 31.82 \\
\hline Nothing & 42 & 38.18 \\
\hline Total & 4 & 3.64 \\
\hline Source Based & $\mathbf{1 1 0}$ & $\mathbf{1 0 0 . 0 0}$ \\
\hline
\end{tabular}

Source: Based on Field Survey, August 2018.

Income:

Table 6 provides the information on daily income and per capita income of scavengers in Amroha city. It is clear from the table that there is a great variation in the daily income among the scavengers. The scavengers, who earn money 4000-8000 per month, are predominant in the city. While almost one-fourth proportion of scavengers earn 8000-12000 rupees per month followed by those who earn less than 4000 rupees per month (21.82 per cent), 12000 18000 rupees per month (13.64per cent), and 18000 rupees per month (5.45 per cent) respectively. Further, this table also explains the per capita monthly income of scavengers in Amroha City. It is depicted that approximately twofifth share of the scavengers have monthly per capita income up to rupees 1000-1500 while only 3.64 per cent of scavengers have per capita monthly income up to rupees above 2500.

Table 6:-Percentage Distribution of Monthly Household's Income and Per Capita.

\begin{tabular}{|l|l|l|l|l|l|}
\hline $\begin{array}{l}\text { Monthly Income (Indian } \\
\text { Rupees) }\end{array}$ & $\begin{array}{l}\text { Numbe } \\
\text { r }\end{array}$ & $\begin{array}{l}\text { Per } \\
\text { cent }\end{array}$ & $\begin{array}{l}\text { Monthly per capita income(Indian } \\
\text { Rupees) }\end{array}$ & $\begin{array}{l}\text { Numbe } \\
\text { r }\end{array}$ & $\begin{array}{l}\text { Perce } \\
\text { nt }\end{array}$ \\
\hline less than 4000 & 24 & 21.82 & Below 1000 & 33 & 30.00 \\
\hline $4000-8000$ & 39 & 35.45 & $1000-1500$ & 43 & 39.09 \\
\hline $8000-12000$ & 26 & 23.64 & $1500-2000$ & 23 & 20.91 \\
\hline $12000-18000$ & 15 & 13.64 & $2000-2500$ & 7 & 6.36 \\
\hline more than 18000 & 6 & 5.45 & above 2500 & 4 & 3.64 \\
\hline TOTAL & $\mathbf{1 1 0}$ & $\mathbf{1 0 0 . 0 0}$ & Total & $\mathbf{1 1 0}$ & $\mathbf{1 0 0 . 0 0}$ \\
\hline
\end{tabular}

Source: Based on Field Survey, August 2018.

\section{Working Hours:}

Table 7 reveals that almost one-fourth scavengers work for less than 6 hours in a day. The scavengers, who do a job for 6 to 10 hours in a day, are predominant in Amroha city. For earning more money, about 18 per cent scavengers work for more than 10 hours in a day.

Table 7:-Percentage Distribution of Scavengers Based on Working Hours.

\begin{tabular}{|l|l|l|}
\hline Working Hours & Number & Percent \\
\hline
\end{tabular}




\begin{tabular}{|l|l|l|}
\hline Less than 6 & 28 & 25.45 \\
\hline 6-10 hours & 62 & 56.36 \\
\hline More than 10 & 20 & 18.19 \\
\hline Total & $\mathbf{1 1 0}$ & $\mathbf{1 0 0 . 0 0}$ \\
\hline
\end{tabular}

Source: Based on Field Survey, August 2018.

\section{Housing:}

Table 8 provides information about houses and household amenities of scavengers in Amroha city. Most of them have no pure air to breathe, pure water to drink, and house to live because their income is too low so they could not afford to live better condition. Nearly three-fourths of them have their own houses, 28 per cent live in the rented house, rest of the scavengers live in the slum and government property. Moreover, the housing condition is very poor, nearly 37 per cent live in kuchcha houses, 27 per cent in semi kuchcha house, 25 per cent live in semi-pucca houses, and only 10 per cent scavengers have the pucca house. This table also gives information about the source of drinking water and fuel. Nearly 30 per cent scavengers obtain water from the public hand pump, 20 per cent from the private hand pump, 22 per cent from public taps, 19 per cent taken from the private tap. Moreover, 31 per cent scavengers use cow dung as fuel, 29 per cent use wood, 20 per cent use tree leaves, and 15per cent use LPG, and only 2 per cent use kerosene for cooking. Besides, Open defecation is one of the major problems in India. Nearly 17 per cent scavengers defecate in open fields. Most of the scavengers (nearly 37 per cent) use the personal toilet, while 30 per cent go outside for public toilets.

Table 8:-Houses and Household Amenities

\begin{tabular}{|l|l|l|}
\hline Status of the House & Numbers & Percent \\
\hline Own & 76 & 69.09 \\
\hline Rented & 31 & 28.18 \\
\hline Any Other & 4 & 3.64 \\
\hline Total & 110 & 100 \\
\hline Type of the House & Numbers & \\
\hline Pucca & 11 & Percent \\
\hline Semi Pucca & 28 & 10 \\
\hline Semi-Kuchcha & 30 & 25.45 \\
\hline Kuchcha & 41 & 27.27 \\
\hline Total & 110 & 37.27 \\
\hline & & 100 \\
\hline Means of Drinking Water & Numbers & \\
\hline Public Hand Pump & 33 & Percent \\
\hline Private Hand Pump & 23 & 30 \\
\hline Public Taps & 25 & 20.91 \\
\hline Private Taps & 21 & 22.73 \\
\hline Others & 8 & 19.09 \\
\hline Total & 110 & 7.27 \\
\hline & & 100 \\
\hline Means of Fuel & Numbers & \\
\hline Cow-Dung & 35 & Percent \\
\hline Wood & 32 & 31.82 \\
\hline Leaves & 23 & 29.09 \\
\hline LPG & 17 & 20.91 \\
\hline Kerosene & 3 & 15.45 \\
\hline Total & 110 & 2.73 \\
\hline & & 100 \\
\hline Types of Toilet & Numbers & \\
\hline Private Toilet & 41 & Percent \\
\hline Public Toilet & 33 & 37.27 \\
\hline Field & 19 & 30 \\
\hline & & 17.27 \\
\hline & \\
\hline
\end{tabular}




\begin{tabular}{|l|l|l|}
\hline Septic Tank & 17 & 15.45 \\
\hline Total & 110 & 100 \\
\hline
\end{tabular}

Source: Based on Field Survey, August 2018.

Table 9 explains the percentage distribution of availability of durable goods in the dwelling of scavengers. Mostly scavengers use the items such as a watch, mobile, television, electric fan and cycle because these items are very useful. The costly items like fridge, washing machine, bike and car are rarely found in scavengers' houses.

Table 9:-Percentage Distribution of Availability of Durable Goods.

\begin{tabular}{|l|l|}
\hline Durable Goods & Percent \\
\hline Mobile & 89.09 \\
\hline Laptop/Computer & 5.45 \\
\hline Radio & 29.09 \\
\hline Television & 60.91 \\
\hline Cycle & 51.82 \\
\hline Bike & 40.00 \\
\hline Car & 4.55 \\
\hline Electric Fan & 68.18 \\
\hline Air Conditioner & 0.91 \\
\hline Inverter & 1.82 \\
\hline Nothing & 6.36 \\
\hline
\end{tabular}

Source: Based on Field Survey, August 2018.

Health:

Table 10 shows the percentage distribution of diseases among scavengers. Due to their unhygienic living conditions, poor nutrition, bad habits as well as doing work without the mask, they suffer from many diseases. Diseases such as asthma, respiration, and skin diseases are very common in scavengers. Nearly one-third of them are the patient of asthma, while 21 per cent suffer from the respirational disease.

Table 10:-Percentage Distribution of Diseases among Scavengers in Amroha city.

\begin{tabular}{|l|l|}
\hline Diseases & Percent \\
\hline Asthma & 34.55 \\
\hline Respiration Problems & 21.82 \\
\hline Skin Diseases & 26.36 \\
\hline Back Pain & 17.27 \\
\hline a headache & 14.55 \\
\hline Nothing & 19.09 \\
\hline
\end{tabular}

Source: Based on Field Survey, August 2018.

Bad Habits:

Table 11 explains the percentage distribution of bad habits among the scavengers. The habits such as smoking, chewing gutkha and tobacco, and drinking are very common in male scavengers. Among all scavengers, nearly 25 per cent are those who do not have any bad habits. The habit of chewing gutkha and tobacco is predominant in scavengers, followed by drinking, smoking, and gambling (55.45 per cent, 51.82 per cent, and 10.91per cent respectively).

Table 11:-Percentage Distribution of Bad Habits among the Scavengers in Amroha City.

\begin{tabular}{|l|l|}
\hline Bad habits & Percent \\
\hline Smoking & 51.82 \\
\hline Chewing Guthka and Tobacco & 60.90 \\
\hline Drinking & 55.45 \\
\hline Gambling & 10.91 \\
\hline No bad habits & 25.45 \\
\hline
\end{tabular}

Source: Based on Field Survey, August 2018. 


\section{Government Facilities:}

The percentage distribution of the various helps received by the scavengers from the government side is given in Table 12. It is clear from the table that mostly scavengers use government facilities in the form of voter identity card, aadhaar card, and bank account. The facilities that assist financially like below poverty line card (BPL Card), scholarship, etc. are provided to a small number of scavengers.

Table 12:-Percentage Distribution of Government Facilities Received by Scavengers in Amroha City.

\begin{tabular}{|l|l|l|}
\hline Facilities & Number & Percent \\
\hline Voter identity & 105 & 95.45 \\
\hline Adhaar card & 79 & 71.82 \\
\hline BPL card & 17 & 15.45 \\
\hline Bank account & 70 & 63.64 \\
\hline Pan card & 3 & 2.73 \\
\hline Scholarship for children in school & 24 & 21.82 \\
\hline Mid-Day Meal & 20 & 18.18 \\
\hline Indra AwasYojna & 8 & 7.27 \\
\hline Pension & 15 & 13.64 \\
\hline Nothing & 2 & 1.82 \\
\hline
\end{tabular}

Source: Based on Field Survey, August 2018.

\section{Socio-economic Causes of Scavenging}

Table 13 depicts the socio-economic causes of scavenging. According to the given table, inheritance and caste is a major cause of scavenging, followed by unemployment, poverty, illiteracy and ignorance causes respectively. More than half of the sampled scavengers accept this occupation by the cause of inheritance and caste. While, nearly 17 per cent, 11 per cent, and 10 per cent engaged due to unemployment, poverty, and illiteracy \& ignorance respectively. Only two scavengers were found who adopted scavenging by passion. Therefore, about 70 per cent scavengers accepted scavenging by social causes, and 30 per cent by economic causes.

Table 13:-Percentage Distribution of Socio-economic Causes of Scavenging in Amroha City.

\begin{tabular}{|l|l|l|l|l|l|}
\hline Causes & Number & Percent & Causes & Number & Percent \\
\hline Economic Causes & 32 & 29.09 & Poverty & 13 & 11.82 \\
\cline { 3 - 6 } & & & Unemployment & 19 & 17.27 \\
\hline \multirow{2}{*}{ Social Causes } & 78 & \multirow{2}{*}{70.91} & Inheritance and cast & 58 & 52.73 \\
\cline { 4 - 6 } & & & Parents death/ husband death/ divorce & 4 & 3.64 \\
\cline { 4 - 6 } & & & Illiteracy and ignorance & 12 & 10.91 \\
\cline { 4 - 6 } & & unskilled & 2 & 1.82 \\
\cline { 4 - 6 } & & Passion & $\mathbf{1 1 0}$ & 1.82 \\
\hline Total & $\mathbf{1 1 0}$ & $\mathbf{1 0 0 . 0 0}$ & & $\mathbf{1 0 0 . 0 0}$ \\
\hline
\end{tabular}

Source: Based on Field Survey, August 2018.

Figure 3: Socio-economic Causes of Scavenging in Amroha City.

Source: Based on Field Survey, August 2018.

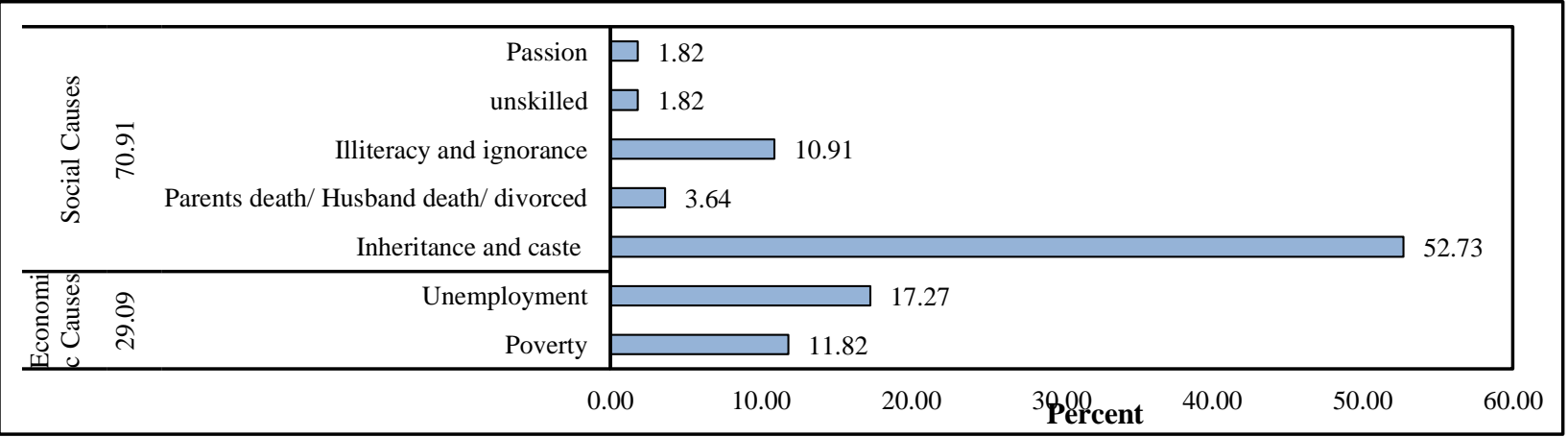




\section{Problems Faced by Scavengers}

Table 14 provides a detailed account of various problems faced by scavengers in Amroha city. It is clear from the table that scavengers face many problems such as low income, unemployment illiteracy, untouchability etc. in Amroha city. Untouchability is a serious problem that is faced by nearly 24 per cent scavengers. Almost one-third of scavengers are those who face the problem of low income, while 29 per cent suffer from the problem of unemployment. Besides, the problems of discrimination, lack of houses lack of electricity, lack of water supply, illiteracy and ignorance are faced by nearly 29 per cent, 31 per cent, 18 per cent, 16 per cent, 18 per cent respectively. Besides, about 10 per cent of scavengers were found who do not face any problem in Amroha City.

Table 14:-Percentage Distribution of Major Problem Faced by Scavengers in Amroha City.

\begin{tabular}{|l|l|}
\hline Problems & Percentage \\
\hline Low income & 35.45 \\
\hline Unemployment & 29.09 \\
\hline Untouchability & 23.64 \\
\hline Lack of houses & 31.82 \\
\hline Lack of Electricity & 18.18 \\
\hline Lack of water supply & 16.36 \\
\hline Illiteracy and ignorance & 18.18 \\
\hline Discrimination at Scavenging spot & 29.09 \\
\hline Discrimination with the child at school, playing sport etc. & 32.73 \\
\hline No problem & 10.90 \\
\hline
\end{tabular}

Source: Based on Field Survey, August 2018.

\section{Conclusions and Recommendations:-}

The overall analysis of the study reveals that scavenging is a major emerging problem in our society. Scavengers mirror the plight of the marginalisation of our modern development upon our culture, tradition, identity, language and economy in Indian cities. Among the scavengers, the number of males is higher than females. Majority of them belong to Hindus. Among them, Bhangi caste is predominant. Moreover, there is mass illiteracy among the scavengers because they do not get register in school due to low income. More than 80 per cent proportion of the scavengers earn up to rupees 12000 per month. Due to their low income and large family size, 30 per cent scavengers get very low per capita income (less than 1000 rupees per month), comes under the poverty line. Therefore, the scavengers, in Amroha city, are living with low income, poor housing condition, lack of education, and social injustice in society. The suggestions from respondents to improve their socio-economic conditions are like that, to provide cheap and easy access to shelter, develop health facilitates, make availability of water and food assistance, open education institutional, introduce easy term institutional loan, develop employment opportunities, distribute land, etc. The government should control the corruption in governmental bodies and improve the efficiency and ability of administrative workers to be committed towards the concerned works \& duties.

\section{References:-}

1. Ali, S. (1994), Socio-Economic Status of Scavengers, Har-Anand Publication, New Delhi.

2. Baruah, A. (2014). The Prohibition of Employment as Manual Scavengers and their Rehabilitation Act, 2013: A Review. Space and Culture, 3, 9-17.

3. Dirks, N. B. (1989). The Original Caste: Power, History and Hierarchy in South Asia. Contribution to Indian Sociology, 3 (1), 59-77.

4. District Handbook of Amroha District, Census, 2011.

5. Ravichandran, B. (2011). Scavenging profession: between class and cast. Economic and Political Weekly, 46 (13), 23-25.

6. Siddaramu, B. (2013). Liberation and rehabilitation of manual scavengers. International Journal of Research in Humanities, Arts and Literature, 1 (2), 29-38.

7. Singh, R. J. (2009). Manual Scavenging as Social Exclusion: A Case Study. Economic and Political Weekly, 44, 15-18.

8. Srivastava, B. N. (1997). Manual Scavenging in India: A Disgrace to country. Concept Publication, New Delhi. 